\title{
Retirement Decisions of Older Czech Male Workers
}

\author{
Kamil Galuščák*
}

February 2002

\begin{abstract}
I analyze the effects associated with the introduction of the earnings test on older Czech males' labor supply in 1996. Using data from the Labor Force Survey, I apply a difference-indifferences estimator to measure the effect of the policy change in the Czech pension scheme using a sample of retired males aged 60 to 64 in 1995 and 1996. I use an age group not affected by the earnings test to separate the effect associated with the implementation of the earnings test. Correcting for sample selection, results indicate that the earnings test decreases the labor supply of retired males affected by the policy change. Their participation reduces by 7.7 percentage points, while hours of work decline by 4.8 hours per week. The response to the earnings test is moderately lower after controlling for the announcement of the policy change. The pecuniary value of the labor supply drop was negligible for the state in 1996, but increased significantly between 1996 and 2000.
\end{abstract}

\begin{abstract}
Abstrakt
Analyzuji vliv výdělkového testu, který byl v České republice zaveden v roce 1996, na nabídku práce starších mužů. Efekt této politiky měřím pomocí odhadu diference v diferencích na vzorku důchodců-mužů z Výběrového šetření pracovních sil ve věku 60 až 64 let v období 1995 a 1996. Vliv výdělkového testu separuji pomocí věkové podskupiny mužů, kteří nebyli zavedením této politiky ovlivněni. Výsledky korigované o výběr vzorku ukazují, že nabídka práce důchodců-mužů, na které se výdělkový test vztahuje, je nižší. Participace poklesla o 7,7 procentního bodu, zatímco počet odpracovaných hodin se snížil o 4,8 týdně. Reakce na výdělkový test je v absolutní hodnotě mírně nižší po odečtení vlivu spojeného s oznámením zavedení politiky. Peněžní hodnota ušlé celkové nabídky práce byla v roce 1996 zanedbatelná, ale významně se zvýšila mezi roky 1996 a 2000.
\end{abstract}

JEL Classification: J26, J22.

Keywords: labor market policy, earnings test, labor supply, retirement.

\footnotetext{
* CERGE-EI, P. O. Box 882, Politických vězňů 7, 11121 Praha, Czech Republic, e-mail: galuscak@volny.cz. I thank Randall Filer, Jan Kmenta, Štěpán Jurajda, Cordelia Reimers, and Ondřej Schneider for their helpful comments. My thanks are also addressed to Costas Meghir who gave me comments on an earlier draft of the paper during my research stay at the Economics Department - University College London in the summer of 1998. The stay was supported by the Tempus Programme of the European Union. I remain responsible for all errors and interpretations.
} 


\section{Introduction}

The objective of public social security is to provide support income during disability or retirement. Tracing the historical origins, retirement appeared as a form of health insurance. Since costs of monitoring the health of older workers were high, insurance companies introduced an age limit. After that age, all workers were eligible for benefits. Public policy of implementing the age limit at which all workers are eligible for old-age retirement benefits is, however, vulnerable to demographic changes. The increasing life expectancy in recent decades weakened the disability concept of retirement. Thus, at present, changes to public social security are being introduced in many countries. These changes include adjusting the age of retirement and restrictions on working pensioners' eligibility for retirement benefits. ${ }^{1}$

The purpose of this paper is to investigate the retirement decisions of older workers in the Czech Republic and to assess the labor supply effects associated with the introduction of the earnings test. In particular, a new law effective since January 1996 introduced a change in the normal retirement age and imposed benefit eligibility constraints for working pensioners. Before January 1996, the normal retirement age was 60 for males, while after January 1996, it has been increasing by 2 months every year until 2006, and after 2007 it will be 62 in the case of males. ${ }^{2}$ An individual is eligible for retirement benefits if he has reached at least the normal retirement age and if he has worked for a particular period before retirement. This implies that some persons are eligible for retirement benefits later than at the normal retirement age. After January 1996, a pension is not payable for a period of 2 years after the date at which a person is entitled for benefits if the income from post-retirement work exceeds twice the minimum subsistence amount. ${ }^{3}$ Future retirement benefits are increased in this case to compensate for the unpaid benefits in the same way as in the case of delayed retirement. The pension is always payable if the person reaches 65 years of age. Before January 1996, there were no benefit eligibility constraints in the case of post-retirement work. However, the validity of employment contracts for pensioners was limited

\footnotetext{
${ }^{1}$ I call the age limit the normal retirement age. In many countries, workers are allowed to retire before the normal retirement age. Their benefits are reduced.

${ }^{2}$ The normal retirement age of females depended and remains dependent on the number of children raised. Therefore, I focus only on males in this paper.

${ }^{3}$ The minimum subsistence amount is a minimum amount of money necessary to cover basic life expenses. It is declared and recognized by the state.
} 
to a period of one year. ${ }^{4}$

In the next section, I briefly summarize the previous literature related to this issue. Then I apply the piece-wise linear budget constraint approach to examine the labor supply effects of the introduction of the earnings test on transitions to retirement and on the pensioners' labor supply. ${ }^{5}$ I use the difference-in-differences estimator applied in Baker and Benjamin (1999) to measure the effect of the implementation of the earnings test rule using a sample of retired males from the Labor Force Survey aged 60 to 64 in 1995 and 1996. The rule affects individuals of age 60 to 61 . I use the age group 62 to 64 to control for other effects not related to the policy change. Section 5 describes the data, while the following section provides results. The last two sections provide policy implications and concluding remarks.

\section{Survey of Literature}

Most earlier empirical studies of the effects of the earnings test on older workers' labor supply in the U.S. are based on the Retirement History Survey. Burtless and Moffitt (1985) were among the first researchers who proposed a life-cycle model of the joint choice of retirement date and hours of work after retirement. Their simulation analysis of the effects of the social security changes revealed that the elimination of the earnings test would increase the post-retirement hours of work only slightly. Similarly, little effect is found on retirement probabilities.

Reimers and Honig (1993) confirmed negligible effects of the elimination of the earnings test on the labor supply of the aged. They estimated the hazard function for white males' labor market reentry after retirement. The budget constraint faced by these individuals is continuous and the earnings test should have no effect on their labor supply under two assumptions. First, retirees face a continuous choice of work hours, and, second, they take into account the actuarial adjustment of the social security benefits postponed as a result of the earnings test. Reimers and Honig found no support for these assumptions. Instead, these authors concluded that the exempt amount affects the labor market reentry and that older males respond to current benefits rather than to social security wealth. Fixed costs of work or lack of acceptable part-time jobs for the aged explain this

\footnotetext{
${ }^{4}$ Rules for retirement before the normal retirement age were not changed in 1995 and 1996. Details of the Czech pension scheme are described in Galuščák (2002).

${ }^{5}$ The piece-wise linear budget constraint approach is adopted in Baker and Benjamin (1999), Friedberg (2000), or Reimers and Honig (1993).
} 
phenomenon.

Whitehouse (1990) analyzed the effects of the earnings test rules on the pensioners' labor supply in the U.K. Using the Family Expenditure Survey, he found no substantial bunching below the earnings test limits. The abolition of the earnings test in the U.K. in 1989 has thus a limited impact on pensioners' labor supply. The proportion of working pensioners is small in the U.K., and their earnings fall far below the exempt amount. Previous improvements to work incentives for the aged had limited impact and did not reverse the long run downward trend in their labor supply.

In the estimation of the effects of the earnings test on older individuals' labor supply, the crucial problem is appropriate controlling for other effects. Friedberg (2000) raised a point that the Retirement History Survey covers a period with little variation of the earnings test rules. She investigated changes in the earnings test that were introduced between 1978 and 1990 using data from the March Current Population Surveys. Friedberg used the behavior of age groups not affected by the earnings test as a control for other changes in the labor supply. Using the piece-wise linear budget constraint approach, she found that older workers bunch substantially at or just below the earnings exempt amount, and that this bunching reacts to the changes in the earnings test. Her results suggest that older workers enjoy greater flexibility in hours of work. ${ }^{6}$ A simulation analysis of removing the earnings test indicates that the effect on hours of work and earnings is strongly positive in this case.

Baker and Benjamin (1999) argued that the age-based isolation of the effects of changes in the earnings test rules is invalidated by dynamic effects. The removal of the earnings test increases the relative compensation of the affected age group. This reduces the labor supply at younger ages. Baker and Benjamin analyzed the sequential elimination of the earnings test in Canada in 1975 and 1977. The control group is separated from the affected group by geography. ${ }^{7}$ They first estimate the difference before and after the policy change. The second difference is geographical. Their difference-in-differences estimates indicate that the abolition of the earnings test is associated with a large increase in weeks of work, while participation is virtually unchanged. These results are consistent with the presence of fixed costs of work or labor market rigidities. Dynamic effects associated with

\footnotetext{
${ }^{6}$ Ruhm (1990) found that over one half of household heads from the Retirement History Survey retire partially from career jobs. He described the importance of "bridge" jobs between career jobs and full retirement.

${ }^{7}$ Two public pension plans cover workers in Quebec and in the rest of Canada.
} 
the policy change are estimated to be minimal.

In this paper, I use a difference-in-differences estimator to analyze the effect of the Czech earnings test on retired males' labor supply in 1996. In particular, I estimate the difference in labor supply between age groups 60 to 61 and 62 to 64 . The other difference is between the years 1995 and 1996.

The institutional framework of the U.S. test is similar to the Czech earnings test. $^{8}$ Based on the data from the Czech Statistical Office and the International Labour Organization on average wages in industries excluding agriculture, hunting, forestry, and fishing, the ratio of the exempt amount for ages after the normal retirement age to the average monthly wage is 0.55 in the Czech Republic, and 0.60 in the United States in 1996. It indicates that the Czech earnings test is moderately more stringent than the U.S. test. Therefore, the Czech earnings test might be expected to have a similar or greater impact on the labor supply of the aged than the test in the United States.

\section{Effects of the Earnings Test}

The role of the actuarial adjustment for unpaid benefits in the case of the earnings test or postponed retirement is unrecognized or neglected in the literature. Reimers and Honig (1993) found that the labor market reentry of retired individuals was not affected when the delayed retirement credit was increased. Similarly, Friedberg (2000) found that the delayed retirement credit does not affect the response to the earnings test.

According to Galuščák (2002), the delayed retirement credit is not large enough to compensate for the males' unpaid retirement benefits in the Czech Republic in 1996. Assuming that older Czech males are farsighted, they ignore the compensation for the unpaid benefits. ${ }^{9}$ Therefore, their labor market behavior is changed after the introduction of the earnings test in 1996. The budget constraint perceived by males affected by the earnings test is piece-wise linear.

Suppose an individual chooses leisure $l$ between zero and unity. Denote $w$ a net wage before retirement, $w^{R}$ a post-retirement net wage, and $B$ a retirement benefit. Before retirement, an individual earns income $Y$ from the wage:

$$
Y=(1-l) w .
$$

\footnotetext{
${ }^{8}$ See Friedberg (2000) and Galuščák (2002) for details on earnings tests in the U.S. and the Czech Republic.

${ }^{9}$ If older workers are myopic, they neglect the compensation even if it is fair. The story of this section remains unchanged in this case.
} 
Before the introduction of the earnings test, a retired individual receives

$$
Y=(1-l) w^{R}+B
$$

Figure 8.1 illustrates budget constraints before the earnings test was introduced. Before retirement, an older worker faces the constraint TM defined in equation (3.1). When an individual retires, he faces a new budget constraint KLM' given by equation (3.2). ${ }^{10}$ The two constraints intersect at a point $\mathrm{L}$ where leisure equals $l_{1}$. Workers who allocate more leisure than $l_{1}$ will retire, while others will continue to work. It follows from equations (3.1) and (3.2) that

$$
l_{1}=1-\frac{B}{w-w^{R}} .
$$

When the earnings test is introduced, a retired person faces the constraint PQRS with a discontinuity between points $Q$ and R, see Figure 8.2. The constraints of persons before and after retirement cross at some point between $\mathrm{Q}$ and $\mathrm{R}$ if $w \frac{E}{E+B}<w^{R}<w$, where $\mathrm{E}$ denotes the exemption amount imposed by the earnings test. The amount of leisure that corresponds to the point $U$ is

$$
l_{2}=1-\frac{E}{w^{R}}
$$

It follows from equations (3.3) and (3.4) that $l_{2}>l_{1}$ if $w \frac{E}{E+B}<w^{R}<w$.

For the post-retirement wage $w^{R}<w \frac{E}{E+B}$, the constraint of a retired individual is PQ'R'S'. This constraint intersects the budget constraint of a worker before retirement (TM) at a point $\mathrm{V}$. The leisure corresponding to the point $\mathrm{V}$ is

$$
l_{3}=1-\frac{B}{w-w^{R}} .
$$

This is the same as the leisure $l_{1}$ given in equation (3.3).

Incentives to retire and to work immediately after retirement are the same after the introduction of the earnings test if individuals face the same budget constraints. When $w^{R}<w \frac{E}{E+B}$, the workers' probabilities to retire are not changed since $l_{3}=l_{1}$. The constraint KLM in Figure 8.1 is identical to PVM in Figure 8.2. In addition, the retirees' post-retirement labor supply is also unchanged for

\footnotetext{
${ }^{10} \mathrm{I}$ assume that $w^{R}<w$. For a person whose pre- and post-retirement gross wage is the same, the net wage is lower after he retires since retired persons face higher income tax from their earnings than workers before retirement. I do not discuss other combinations of pre- and post-retirement wage since they do not change the predictions drawn in this section.
} 
those who retire in 1996 or 1995 since only workers allocating more leisure than $l_{1}$ in 1995 and $l_{3}$ in 1996 retire.

When $w \frac{E}{E+B}<w^{R}<w$, the constraint is still KLM in 1995, but changes to PQUM in 1996. Since $l_{2}>l_{1}$, it implies that the workers' probability to retire as well as the retirees' post-retirement labor supply is reduced in 1996. Applying the data from 1996, we see that incentives to retire and to supply work after retirement are lower for individuals who face post-retirement wage between $55 \%$ and $100 \%$ of their pre-retirement wage. ${ }^{11}$

Persons who retired before the introduction of the earnings test face the budget constraint KLM' in 1995, and PQRS in 1996, see Figures 8.1 and 8.2. Some of those pensioners who would choose less leisure than $l_{2}$ in 1995 will increase their leisure to $l_{2}$ in 1996. They shift to a higher indifference curve by moving to the kink Q in the 1996 budget constraint. The labor supply of pensioners decreases on average in 1996.

\section{Estimation}

The estimation of the effects associated with the introduction of the earnings test yields inappropriate results when the anticipation of the policy change is neglected. In the Czech Republic, the law introducing the earnings test was passed by Parliament in June 1995, and came into force in January 1996. During the second half of 1995, workers between 60 and 61 years of age who had not retired before June 1995 and who knew that they would be affected by the earnings test anticipated the policy change. Since the compensation for unpaid benefits due to the earnings test is not fair, they either postpone retirement or retire and increase the post-retirement labor supply. Similarly, some pensioners who retired before June 1995 and who are in the age group affected by the earnings test in 1996 will increase their labor supply between July and December 1995. The estimate of the policy change on the pensioners' labor supply will be biased towards greater decline if the announcement is neglected. On the other hand, the bias is mitigated since workers who postpone their retirement due to the announcement are those supplying more post-retirement hours of work. Therefore, I do not follow the remedy used by Baker and Benjamin (1999) who excluded the year preceding the

\footnotetext{
${ }^{11}$ According to the Czech Statistical Office, the average retirement benefit was 4500 CZK per month, and the exempt amount (earnings limit) imposed by the earnings test was $5400 \mathrm{CZK}$ per month in 1996.
} 
date of the reform. However, I present results corrected for the announcement of the policy change to provide a comparison.

I am not able to estimate changes in retirement probabilities between 1995 and 1996 because of lack of data. ${ }^{12}$ Instead, I focus on analyzing the labor supply of retired males. I measure the effect of the policy change by a difference-indifferences estimator. I use the age group unaffected by the change to control for other effects not related to the introduction of the earnings test. Using the sample of retired males aged 60 to 64 , I estimate the equation

$$
\begin{aligned}
\text { hour }_{i}= & a_{0}+a_{1} * \text { year } 1996+a_{2} * \text { age60_61 }+a_{3} * \text { year1996*age60_61 } \\
& +\sum_{j} a_{j} * x_{i j}+u_{i}
\end{aligned}
$$

by tobit. The dependent variable is the number of hours worked weekly. A dummy variable year 1996 is the effect of 1996, while age60_61 is a dummy capturing effects specific to the group aged 60 and 61 . The estimate of the coefficient $a_{3}$ measures the labor supply effect of the policy change on males of age 60 or 61 in 1996 . Predictions drawn in the previous section suggest that the estimate of $a_{3}$ has a negative sign.

In equation (4.1), a set of variables $x_{i j}$ controls for personal, job-related, and macroeconomic variables. The linear term of age in equation (4.1) is the identification assumption. It allows one to estimate the effect of the earnings test based on specific age dummies after controlling for the labor supply effect of age. According to Friedberg (2000), the estimate of the coefficient on age should have a negative sign since the labor supply decreases for older individuals, while the effect of a higher level of education (completed at least secondary school) is positive. A positive effect of a higher level of education on the labor supply is also estimated in Burtless and Moffitt (1985). Reimers and Honig (1993) report a negative labor supply response of poor health. Poor health reduces the participation of older workers according to the results in Burtless and Moffitt (1985). The effect of marital status is not straightforward. Burtless and Moffitt (1985) estimate a negative labor supply response of married individuals. On the contrary, Friedberg (2000) arrives at ambiguous results. Raising the exempt amount for individuals aged 65 to 71 in 1978 yields a positive labor supply response of married persons. The effect is negative and not statistically significant in the case of the elimination

\footnotetext{
${ }^{12}$ I derive some results on the change in retirement between 1995 and 1996 using aggregate data in Section 7.
} 
of the earnings test for persons aged 70 to 71 in 1983. Blau (1998) analyzed the joint labor force behavior of older couples in the U.S. Using the data from the Retirement History Survey, he found an incidence of joint retirement as a result of preferences for shared leisure. His results indicate that there is a strong association between transition probabilities of one spouse and the labor force status of the other spouse. Therefore, I include a dummy variable that equals one if the wife is working. I expect a positive effect of this variable on husband's labor supply.

Among other explanatory variables comprising $x_{i j}$ in equation (4.1), an occupation dummy equals one for white collar workers. Reimers and Honig (1993) found a positive effect of this variable on the labor market reentry after retirement. They also estimated a positive effect of a dummy indicating that the career job was in the finance, public administration, or business or personal service industry. Therefore, I construct a dummy variable that equals one if the present or last job was white collar, and two dummies indicating the present or last employment in agriculture or in manufacturing or construction. Both industrial dummies should have a negative effect on the pensioners' labor supply. The last regressor in equation (4.1) is the unemployment rate from districts where individuals reside. This variable should have a negative effect on the labor supply. Finally, $u_{i}$ is an error term distributed with zero mean and constant variance.

The data analyzed in this paper do not report wages. Omitting this variable biases the estimates on education, occupation, and on the industrial dummy indicating employment in agriculture. The bias from omitting the wage rate is ambiguous, since the sign on the wage is ambiguous due to the offsetting income and substitution effects.

Estimating equation (4.1) by tobit accounts for left-censored observations at zero hours of work. The results show the overall, "reduced-form" labor supply effect of the earnings test. In order to separate the effect on hours of work from the effect on participation, I estimated equation (4.1) by maximum-likelihood using the Heckman (1979) selection procedure. The key problem is to identify exclusion variables that determine the selection equation, but that do not explain hours of work. Results in Blau (1998) suggest that participation is strongly associated with marital status. Therefore, I experiment with marital status as the exclusion variable. I also use industrial dummies as exclusion variables since average weekly hours of work are virtually the same across industries in the data from the Labor Force Survey. 


\section{Data}

The sample is drawn from the Labor Force Survey. It is a quarterly data source surveying approximately $1 \%$ of all households in the Czech Republic. In each quarter, information on personal as well as labor market characteristics of all persons of age more than 15 living in a particular household is recorded. The sample design is a rotating panel, replacing one fifth of the households in each quarter, so that each household is interviewed each quarter over a five-quarter period. The first quarter of a year starts in December, the second quarter in March, the third in June, and the fourth in October.

There are two measures of labor force status. The first one complies with the International Labour Organization standards. A person is considered to be a worker if he had paid work during the previous week. The alternative measure of labor force is based on the respondent's answer to a question: "What was your economic status during the previous week?"

Age is reported in whole years. However, having five observations for each individual, I was able to measure the age more precisely since a change of age is observed in the data. Assume an indivudual is of age 59 in a quarter $t-1$ and 60 in $t$. His age is, therefore, between 60 and 60 years and 3 months in the quarter $t$, between 60 years and 3 months and 60 years and 6 months in $t+1$, etc.

The sample consists of all males who considered themselves to be old-age pensioners and were of age 60 or more and less than 65 in the second, third, and fourth quarters of 1995 and $1996 .{ }^{13}$ In order to account for the shift in the normal retirement age, I dropped individuals of age between 60 and 60 years and 3 months in 1996 from the sample. I assume that all individuals are eligible for retirement benefits at the normal retirement age that was 60 in 1995 and 60 years and 2 months in 1996. Since the earnings test is applied in the period of two years starting from the date when an individual is eligible for retirement benefits, this assumption is crucial because some persons are eligible for benefits later than at the normal retirement age. The Czech Social Security Administration records indicate that $0.5 \%$ of males at the normal retirement age are not eligible for benefits since they do not meet the requirement for the minimum number of years contributed to the pension scheme. This justifies the assumption. Similarly, I did not include retired males of age 65 or more in the sample. ${ }^{14}$

\footnotetext{
${ }^{13}$ Since quarters are seasonal, it is not possible to separate effects related to the year 1996 in the data from the first quarter of 1996.

${ }^{14}$ The earnings test is not in effect at age 65 and above. The number of observations is low
} 
The data are matched with district level unemployment rates. The unemployment data are from the district labor offices data recorded at the Ministry of Labor of the Czech Republic.

Table 8.1 reports the sample statistics. The sample consists of 6564 males aged 60 to 64 observed in the second, third, and fourth quarters of 1995 and 1996. There are 1880 observations on positive hours of work. The average number of hours worked per week is 10.24 overall, and 35.74 for workers. $12 \%$ of all males had completed secondary or higher education, while this number increases to $21 \%$ for those working. This suggests that the effect of a higher level of education on the labor supply is positive. Similar observations can be drawn for other variables in Table 8.1.

\section{Results}

I begin by comparing the age profiles of labor supply and retirement using a sample of all males aged 55 to 70 . Figure 8.3 shows that a substantial number of males retire within two years after the normal retirement age. This finding is not surprising: the Czech pension scheme has a significant effect on retirement and on labor force participation. The proportion of inactive males is lower than the share of pensioners more than 60 years old. This means that some retired individuals are active in the labor market. A drop in the share of retired males at age 60 in 1996 is explained by the shift in the normal retirement age. On the other hand, there is a significant decline in the number of males out of the labor force at age 62 to 64 . This indicates an increased economic activity of persons in that age group in 1996.

Figure 8.4 reports a decline in the labor supply at age 60, while retired males of age 62 to 64 supply more work in 1996 than in 1995. Figure 8.5 separates hours of work from the overall labor supply. Working pensioners of age 60 and 61 supply less hours of work, while no difference in hours of work is observed after age $61 .{ }^{15}$ These findings indicate that participation in the labor market is increased in 1996 for all pensioners aged 60 to 64, while in the case of working pensioners, hours of work are reduced at age 60 and 61 as a result of the policy change.

Table 8.2 shows that hours of work are increased significantly from 8.5 to 11.6 per week for pensioners aged 62 to 64 . The F statistics, based on the comparison

\footnotetext{
for this age group so that it cannot be used as a control group.

${ }^{15}$ The number of observations is low at ages before 60 . The observations are not reliable for these ages in Figures 8.4 and 8.5.
} 
of between-groups sum of squares and within-groups sum of squares, indicate that the difference is significant at the level better than $1 \%$. The change goes through participation since hours of work are virtually unchanged for this age group. Working pensioners' hours of work are unambiguously reduced from 38.6 to 34.4 for age 60 and 61 . The effect of the earnings test on the labor supply in the age group 60 to 61 is outweighed by the increase in participation in the whole sample. Hence, the overall labor supply is virtually unchanged at age 60 to 61 between 1995 and 1996.

The estimation of equation (4.1) sheds more light on what the effect of the earnings test is after controlling for other effects not related to the policy change. The first column of Table 8.3 reports the tobit coefficients of equation (4.1). The earnings test reduces the overall labor supply of pensioners affected by the policy change by 11.8 hours per week. The effect of year 1996 is positive, suggesting that the labor supply of all males in the sample is increased in 1996. In order to test for heteroskedasticity, I estimated equation (4.1) by ordinary least-squares. The Cook-Weisberg test for heteroskedasticity strongly rejects the hypothesis of constant variance.

Other columns of Table 8.3 show the results of the estimates corrected for sample-selection bias (Heckman 1979) with White (1980) estimates of standard errors correcting for heteroskedasticity. Standard errors are also corrected for clustering on persons' identification since the sample has repeated observations on the same persons and these observations are not independent. I used two industrial dummy variables denoting employment in agriculture and in manufacturing or construction as exclusion variables. ${ }^{16}$ Contrary to expectations, marital status does not determine the participation equation, implying that it cannot be employed as an exclusion variable. The estimate of Heckman's $\lambda$ is significant, indicating that the selection cannot be neglected.

The Heckman results suggest that hours of work of all working pensioners in the sample do not change significantly between 1995 and 1996. However, participation increased by 9.3 percentage points in $1996 .{ }^{17}$ This overall change helps separate the effect of the earnings test affecting males aged 60 to 61 in 1996 who decrease both their participation and hours of work. Participation is reduced by

\footnotetext{
${ }^{16}$ Heckman estimates in Table 8.3 did not change significantly when I used only one of these two variables as an exclusion variable.

${ }^{17}$ Hours of work do not change significantly in the Heckman results. Hence, the rise of 9.3 percentage points in participation is equivalent to an increase of 11.3 hours per week according to the tobit results.
} 
7.7 percentage points, while hours of work drop by 4.8 hours per week as a response to the policy change. This result is in accordance with the non-parametric analysis that indicates that males aged 60 to 61 reduced hours of work by 4.2 hours per week (Table 8.2). The overall labor supply effect of the earnings test is, according to the tobit results, -11.8 hours per week.

The labor supply declines with age. Including the square of age in equation (4.1) leaves other Heckman estimates almost unchanged. It indicates that the estimates of the labor supply effects of the earnings test are robust to the identification assumption. Coefficients on age and its square are, in addition, jointly and separately insignificant. Higher education increases participation in the labor market by 15.6 percentage points, while hours of work are virtually unchanged. Poor health has a significant effect on the labor supply. It reduces participation by 9.7 percentage points, and hours of work by 4.8 hours per week. Both tobit and Heckman estimates of the effects of age, higher education, and poor health have the signs expected from other literature.

The tobit estimate of the effect of marital status does not tell us that married males significantly change their labor supply in 1996. The Heckman estimates of the effect of marital status indicate that married males do not change their participation significantly, while hours of work are reduced by 3.1 per week. The labor supply of older retired males is strongly related to the labor force status of their wives. A working spouse increases the participation of her husband by 12.0 percentage points, and hours of work by 3.7 hours per week. The overall effect is 14.6 hours per week according to the tobit results. This finding is in accordance with the results reported in Blau (1998), who found that labor force status and retirement are jointly determined among older couples in the U.S.

Contrary to the results in Reimers and Honig (1993), the tobit and Heckman estimates of the effect of occupation provide a strong negative relationship between white collar jobs and the labor supply. The participation of white collar pensioners is reduced by 7.7 percentage points in the sample, while hours of work are reduced by 3.2 hours per week. The overall labor supply is reduced by 13.8 hours per week. The Heckman results indicate that employment in agriculture reduces the participation in the labor market by 17.4 percentage points. The participation is decreased by 15.0 percentage points for males employed in manufacturing or construction.

Effects related to the economy are estimated using district unemployment rates. The Heckman estimate indicates that participation declines by 2.3 percentage points when the rate of unemployment rises by 1 percentage point, while hours 
of work do not change significantly. This is consistent with the tobit estimate of a decrease of 2.8 hours per week in the overall labor supply. It suggests that regions with higher unemployment are associated with less labor market opportunities for pensioners.

The results are robust to the size of the control group. Using males aged 63 or 64 as a control group leaves Heckman estimate of the effect of marital status insignificant in the hours equation, while Heckman and tobit estimates of other effects are almost unchanged (Table 8.4).

I similarly tested how the announcement of the policy change affects the results. In order to measure the 1996-effect with respect to the period before the announcement, one needs to omit observations from the period between the day of the announcement and the end of 1995. Therefore, I dropped observations from the third and fourth quarters of 1995 from the sample. The size of the sample was reduced to 4295 observations. After controlling for the announcement, the hours of work are reduced by 3.6 hours per week and participation is insignificantly decreased by 5.9 percentage points, while other Heckman estimates are virtually the same (Table 8.5). The tobit results indicate that the overall labor supply is reduced by 8.2 hours per week. The estimates of the labor supply effect are lower in absolute terms than the results in Table 8.3, and are less significant since the sample is reduced. The response to the earnings test is moderately lower after controlling for the announcement of the policy change.

The results are drawn using all durations of jobs in the sample. In 1995, a worker had to switch jobs after accepting benefits. In addition, pensioners were eligible for retirement benefits when the duration of their post-retirement work was 1 year or less than 1 year. That requirement was replaced by the earnings test in 1996. However, due to a legislative error, workers were allowed to accept pensions without switching jobs in 1996. Excluding pensioners with jobs longer than 1 year reduces the sample by 1090 observations. The tobit and the Heckman estimates displayed in Table 8.6 differ from the results presented in Table 8.3. In particular, the Heckman estimates of the labor supply effect of the earnings test are lower. The participation is reduced by 5.2 percentage points, and hours of work are decreased by 3.5 hours per week. However, reducing the sample by excluding jobs of duration more than 1 year erroneously reduces the number of working pensioners in 1996. 


\section{Policy Implications}

The results of this paper indicate that retired males whose earnings are above the exempt amount reduce their labor supply. The participation of all males at age 60 to 61 is decreased by 7.7 percentage points and hours of work by $12.3 \%$ according to the Heckman results from Table 8.3. ${ }^{18}$ To provide a comparison, the Czech earnings test has a somewhat stronger effect on hours of work than the less stringent test in the United States. ${ }^{19}$

Table 8.7 displays the pecuniary value of the loss in the retired males' labor supply in 1996. According to the Czech Statistical Office, the average wage was 6455 CZK for 4647 employed retired males in $1996 .{ }^{20}$ I used the age profile of retired males from Czech Social Security Administration records to derive the share of employed retired males of age 60 to 61 among all employed male pensioners. The drop in the participation of 7.7 percentage points is then equivalent to 13.5 million CZK. Similarly, the loss in hours worked is 7.1 million CZK. In total, the earnings test reduced the pecuniary value of the labor supply by 20.6 million CZK. This represents $0.001 \%$ of the nominal GDP in 1996. The loss in participation was $65.6 \%$ of the total loss, while the loss in hours of work was $34.4 \%$. Applying recent data on average post-retirement wages and the number of working pensioners, the total loss increased to 42.7 million CZK in 2000. The GDP share increased to $0.002 \%$. This indicates that the labor supply loss entailed by the earnings test was negligible in 1996, but has doubled thereafter.

The other effect of the earnings test not estimated in this paper is on the probability of transitions from work to retirement. Czech Social Security Administration records indicate that the number of retired males decreased by $20.5 \%$ at age 60 to 61 , and by $6.0 \%$ at age 62 to 64 between the years 1995 and 1996 . The shift in the normal retirement age by 2 months in 1996 potentially reduced the number of pensioners by $8.3 \%$ at age 60 to 61 . Assuming that the number of pensioners decreased by $6.0 \%$ in all age groups between 60 and 64, the number of

\footnotetext{
${ }^{18}$ Hours of work declined by 4.75 per week. This is $12.3 \%$ of the average weekly hours of work for males aged 60 to 61 in 1995 (Table 8.2).

${ }^{19}$ Friedberg (2000) found that eliminating the U.S. earnings test would raise average hours of work by $5.3 \%$ for persons at or above the exempt amount. While individuals below the exempt amount are not affected, the effect for all individuals in the age group potentially affected by the earnings test is even lower.

${ }^{20}$ The Czech Statistical Office provides the data from a sample of employers. The data are not adjusted to the economy-wide level. Hence, the effect of the earnings test calculated in Table 8.7 is underestimated.
} 
pensioners at age 60 to 61 is reduced by $7.7 \%$ as a response to the introduction of the earnings test. Using data from Czech Social Security Administration records, the number of new pensioners was 22,664 at age 60 to 61 in 1995. The number of new pensioners was reduced by 1899 persons after the introduction of the earnings test in 1996. Since the average new benefit was 5597 CZK for males according to the Czech Statistical Office, the pecuniary value of postponed retirement benefits was roughly 128 million CZK in $1996 .^{21}$

In 1996, the pecuniary value of postponed retirement benefits of persons delaying retirement after the test is introduced is greater than the loss in the retired males' labor supply. Hence, the government's net revenues increased in 1996 as a response to the policy change, indicating that the effect of the policy change was positive for the state in that year. However, the value of the retired males' labor supply loss has doubled between 1996 and 2000. This suggests that the positive effect of the earnings test has diminished after 1996. Using the results of this paper, the labor supply effect of the earnings test should be evaluated using recent data on new pensioners.

\section{Conclusions}

Comparing budget constraints before and after the introduction of the earnings test implies that male workers whose post-retirement wage is between $55 \%$ and $100 \%$ of their pre-retirement wage are less likely to retire and supply less work after retirement in 1996 than in 1995. In addition, some retired older males reduce the post-retirement labor supply in 1996.

Correcting for sample selection, I found that the earnings test unambiguously reduced both the participation and hours of work of retired males aged 60 and 61 in 1996. The estimate of Heckman's $\lambda$ is significant, indicating that the selection cannot be neglected. Results are robust to the choice of the exclusion variables, to the identification assumption, and to the size of the control age group. The response to the earnings test is moderately lower in absolute terms after controlling for the announcement of the policy change.

The pecuniary value of the retired males' labor supply drop is negligible in absolute value and as a share of GDP in 1996. Its size has, however, increased significantly between 1996 and 2000. In 1996, the pecuniary value of retirement

\footnotetext{
${ }^{21}$ The data on new pensioners in 1996 were not available at the time of the study. Therefore, I measure the change in retirement between 1995 and 1996 using the age profiles of all retired males from Czech Social Security Administration records.
} 
benefits of persons delaying their retirement as a response to the policy change is greater than the loss in the retired males' labor supply. However, the change in retirement between 1995 and 1996 is measured imprecisely, and, in addition, the pecuniary value of the retired males' labor supply loss is underestimated. 


\section{References}

[1] Baker, Michael and Dwayne Benjamin (1999). "How Do Retirement Tests Affect the Labour Supply of Older Men?," Journal of Public Economics 71: $27-51$.

[2] Blau, David M. (1998). "Labor Force Dynamics of Older Married Couples," Journal of Labor Economics 16(3): 595-629.

[3] Burtless, Gary and Robert A. Moffitt (1985). "The Joint Choice of Retirement Age and Postretirement Hours of Work," Journal of Labor Economics 3(2): 209-236.

[4] Friedberg, Leora (2000). "The Labor Supply Effects of the Social Security Earnings Test," The Review of Economics and Statistics 82(1): 48-63.

[5] Galuščák, Kamil (2002). "Labor Market Incentives of Public Pension Schemes," Ph.D. dissertation, CERGE-EI.

[6] Heckman, James J. (1979). "Sample Selection Bias as a Specification Error," Econometrica 47(1): 153-161.

[7] Reimers, Cordelia and Marjorie Honig (1993). "The Perceived Budget Constraint under Social Security: Evidence from Reentry Behavior," Journal of Labor Economics 11(1): 184-204.

[8] Ruhm, Christopher J. (1990). "Bridge Jobs and Partial Retirement," Journal of Labor Economics 8(4): 482-501.

[9] White, H. (1980). "A Heteroskedasticity-Consistent Covariance Matrix Estimator and a Direct Test for Heteroskedasticity," Econometrica 48: 817-830.

[10] Whitehouse, Edward (1990). "The Abolition of the Pensions 'Earnings Rule'," Fiscal Studies 11(3): 55-70. 


\begin{tabular}{|c|c|c|}
\hline & All & Working \\
\hline Number of observations & 6564 & 1880 \\
\hline Number aged 60-61 & 2456 & 715 \\
\hline Number aged 62-64 & 4108 & 1165 \\
\hline Hours worked & $10.24(17.62)$ & $35.74(13.11)$ \\
\hline Age 60-61 & $0.37(0.48)$ & $0.38(0.49)$ \\
\hline Year 1996 & $0.47(0.50)$ & $0.53(0.50)$ \\
\hline Age & $62.46(1.38)$ & $62.41(1.37)$ \\
\hline Higher education & $0.12(0.32)$ & $0.21(0.41)$ \\
\hline Poor health & $0.08(0.28)$ & $0.05(0.21)$ \\
\hline Married & $0.90(0.30)$ & $0.90(0.30)$ \\
\hline Working spouse & $0.24(0.43)$ & $0.34(0.47)$ \\
\hline White collar & $0.54(0.50)$ & $0.44(0.50)$ \\
\hline Job in agriculture & $0.15(0.36)$ & $0.10(0.30)$ \\
\hline District unemployment rate $(\%)$ & $2.87(1.70)$ & $2.56(1.66)$ \\
\hline
\end{tabular}

Notes: mean values if not otherwise specified, standard deviations in parentheses.

Table 8.1: Summary statistics.

\begin{tabular}{|c|c|c|c|c|}
\hline & \multicolumn{2}{|c|}{ All } & \multicolumn{2}{c|}{ Working } \\
\hline Age & $\mathbf{1 9 9 5}$ & $\mathbf{1 9 9 6}$ & $\mathbf{1 9 9 5}$ & $\mathbf{1 9 9 6}$ \\
\hline $60-61$ & $11.1(1282)$ & $10.2(1174)$ & $38.6(369)$ & $34.4^{* * *}(346)$ \\
\hline $62-64$ & $8.5(2171)$ & $11.6^{* * *}(1937)$ & $35.8(516)$ & $34.7(649)$ \\
\hline 60 & $12.0(622)$ & $10.1^{*}(464)$ & $38.6(193)$ & $34.6^{* * *}(136)$ \\
\hline 61 & $10.3(660)$ & $10.2(710)$ & $38.7(176)$ & $34.4^{* * *}(210)$ \\
\hline 62 & $9.5(727)$ & $12.0^{* * *}(673)$ & $36.5(190)$ & $35.4(229)$ \\
\hline 63 & $8.7(699)$ & $11.3^{* * *}(672)$ & $36.3(168)$ & $34.7(219)$ \\
\hline 64 & $7.3(745)$ & $11.6^{* * *}(592)$ & $34.5(158)$ & $34.1(201)$ \\
\hline $60-64$ & $9.5(3453)$ & $11.1^{* * *}(3111)$ & $37.0(885)$ & $34.6(995)$ \\
\hline
\end{tabular}

Notes: $*$ difference significant at 10 percent, ${ }^{* *}$ at 5 percent, *** at 1 percent; the number of observations in parentheses.

Table 8.2: Average weekly hours of work. 


\begin{tabular}{|l|l|l|l|}
\hline & Tobit & \multicolumn{2}{|l|}{ Heckman selection } \\
\hline Indep. $\backslash$ Dep. variable & hours & hours & participation $^{++}(\mathrm{dF} / \mathrm{dx})$ \\
\hline Age60_61 & $1.55(3.06)$ & $1.43(1.77)$ & 0.004 \\
\hline Year 1996 & $11.27^{* * *}(1.80)$ & $0.92(1.20)$ & $0.093^{* * *}$ \\
\hline Age60_61*year1996 & $-11.77^{* * *}(2.92)$ & $-4.75^{* * *}(1.65)$ & $-0.077^{* * *}$ \\
\hline Age & $-2.58^{* * *}(0.94)$ & $-0.87(0.60)$ & $-0.018^{*}$ \\
\hline Higher education & $16.92^{* * *}(2.11)$ & $1.62(1.66)$ & $0.156^{* * *}$ \\
\hline Poor health & $-15.33^{* * *}(2.94)$ & $-4.79^{* *}(2.34)$ & $-0.097^{* * *}$ \\
\hline Married & $-2.34(2.38)$ & $-3.05^{*}(1.79)$ & -0.009 \\
\hline Working spouse & $14.62^{* * *}(1.61)$ & $3.73^{* * *}(1.19)$ & $0.120^{* * *}$ \\
\hline White collar & $-13.82^{* * *}(1.66)$ & $-3.18^{* *}(1.29)$ & $-0.077^{* * *}$ \\
\hline Job in agriculture & $-23.63^{* * *}(2.31)$ & & $-0.174^{* * *}$ \\
\hline Job in manuf. or constr. & $-15.41^{* * *}(1.77)$ & & $-0.150^{* * *}$ \\
\hline District unempl. rate & $-2.77^{* * *}(0.43)$ & $-0.36(0.37)$ & $-0.023^{* * *}$ \\
\hline Heckman's $\lambda$ & & $8.59^{* * *}(2.18)$ & \\
\hline Number of observations & 6564 & 1880 & 6564 \\
\hline Log likelihood & -11900 & -11014 & \\
\hline
\end{tabular}

Notes: coefficients if not otherwise specified; standard errors in parentheses; * significant at 10 percent, ${ }^{* *}$ at 5 percent, $* * *$ at 1 percent; + standard errors corrected for heteroskedasticity; ++ marginal effects of changes in dependent variables (discrete changes in dummies).

Table 8.3: Tobit and Heckman (1979) estimates. 


\begin{tabular}{|l|l|l|l|}
\hline & Tobit & \multicolumn{2}{|l|}{ Heckman selection } \\
\hline Indep. $\backslash$ Dep. variable & hours & hours & participation $^{++}(\mathrm{dF} / \mathrm{dx})$ \\
\hline Age60_61 & $0.82(4.88)$ & $1.63(2.92)$ & 0.008 \\
\hline Year 1996 & $12.36^{* * *}(2.25)$ & $0.82(1.49)$ & $0.099^{* * *}$ \\
\hline Age60_61*year1996 & $-12.75^{* * *}(3.23)$ & $-4.75^{* * *}(1.85)$ & $-0.082^{* * *}$ \\
\hline Age & $-2.96^{* *}(1.46)$ & $-0.77(0.87)$ & -0.023 \\
\hline Higher education & $16.30^{* * *}(2.44)$ & $0.39(1.86)$ & $0.149^{* * *}$ \\
\hline Poor health & $-16.67^{* * *}(3.38)$ & $-5.32^{*}(2.79)$ & $-0.105^{* * *}$ \\
\hline Married & $-0.29(2.71)$ & $-1.94(1.89)$ & 0.004 \\
\hline Working spouse & $12.94^{* * *}(1.85)$ & $2.71^{* *}(1.24)$ & $0.105^{* * *}$ \\
\hline White collar & $-12.70^{* * *}(1.88)$ & $-2.60^{*}(1.35)$ & $-0.068^{* *}$ \\
\hline Job in agriculture & $-24.32^{* * *}(2.64)$ & & $-0.173^{* * *}$ \\
\hline Job in manuf. or constr. & $-15.20^{* * *}(2.01)$ & & $-0.146^{* * *}$ \\
\hline District unempl. rate & $-3.35^{* * *}(0.49)$ & $-0.13(0.40)$ & $-0.028^{* * *}$ \\
\hline Heckman's $\lambda$ & & $6.74^{* * *}(2.61)$ & \\
\hline Number of observations & 5164 & 1461 & 5164 \\
\hline Log likelihood & -9274 & -8574 & \\
\hline
\end{tabular}

Notes: coefficients if not otherwise specified; standard errors in parentheses; * significant at 10 percent, ${ }^{* *}$ at 5 percent, $* * *$ at 1 percent; + standard errors corrected for heteroskedasticity; ++ marginal effects of changes in dependent variables (discrete changes in dummies).

Table 8.4: Tobit and Heckman (1979) estimates: control group aged 63 and 64 . 


\begin{tabular}{|l|l|l|l|}
\hline & Tobit & \multicolumn{1}{|l|}{ Heckman selection } \\
\hline Indep. $\backslash$ Dep. variable & hours & hours & participation $^{++}(\mathrm{dF} / \mathrm{dx})$ \\
\hline Age60_61 & $0.03(4.31)$ & $1.12(2.34)$ & -0.006 \\
\hline Year 1996 & $9.98^{* * *}(2.42)$ & $0.72(1.40)$ & $0.087^{* * *}$ \\
\hline Age60_61*year1996 & $-8.16^{* *}(3.90)$ & $-3.64^{*}(2.03)$ & -0.059 \\
\hline Age & $-1.70(1.11)$ & $-0.46(0.68)$ & -0.014 \\
\hline Higher education & $17.02^{* * *}(2.50)$ & $1.84(1.67)$ & $0.177^{* * *}$ \\
\hline Poor health & $-15.66^{* * *}(3.39)$ & $-4.79^{*}(2.54)$ & $-0.107^{* * *}$ \\
\hline Married & $-1.25(2.77)$ & $-3.63^{*}(1.90)$ & 0.003 \\
\hline Working spouse & $15.65^{* * *}(1.86)$ & $5.12^{* * *}(1.30)$ & $0.130^{* * *}$ \\
\hline White collar & $-13.33^{* * *}(1.92)$ & $-3.08^{* *}(1.33)$ & $-0.082^{* * *}$ \\
\hline Job in agriculture & $-23.92^{* * *}(2.74)$ & & $-0.191^{* * *}$ \\
\hline Job in manuf. or constr. & $-16.04^{* * *}(2.04)$ & & $-0.165^{* * *}$ \\
\hline District unempl. rate & $-3.35^{* * *}(0.50)$ & $-0.63^{*}(0.38)$ & $-0.029^{* * *}$ \\
\hline Heckman's $\lambda$ & & $9.20^{* * *}(1.99)$ & \\
\hline Number of observations & 4295 & 1291 & 4295 \\
\hline Log likelihood & -8046 & -7456 & \\
\hline
\end{tabular}

Notes: coefficients if not otherwise specified; standard errors in parentheses; * significant at 10 percent, $* *$ at 5 percent, $* * *$ at 1 percent; + standard errors corrected for heteroskedasticity; ++ marginal effects of changes in dependent variables (discrete changes in dummies).

Table 8.5: Tobit and Heckman (1979) estimates after correcting for the announcement of the policy change. 


\begin{tabular}{|l|l|l|l|}
\hline & Tobit & \multicolumn{2}{|l|}{ Heckman selection } \\
\hline Indep. $\backslash$ Dep. variable & hours & hours & participation $^{++}(\mathrm{dF} / \mathrm{dx})$ \\
\hline Age60_61 & $1.27(4.98)$ & $-1.35(2.42)$ & 0.007 \\
\hline Year 1996 & $10.69^{* * *}(3.02)$ & $-0.30(1.51)$ & $0.043^{* * *}$ \\
\hline Age60_61*year1996 & $-15.85^{* * *}(4.69)$ & $-3.52^{*}(2.10)$ & $-0.052^{* *}$ \\
\hline Age & $-6.33^{* * *}(1.58)$ & $-2.06^{* * *}(0.78)$ & $-0.022^{* * *}$ \\
\hline Higher education & $20.12^{* * *}(3.51)$ & $0.52(1.97)$ & $0.094^{* * *}$ \\
\hline Poor health & $-19.23^{* * *}(4.94)$ & $-4.32^{* *}(2.20)$ & $-0.062^{* * *}$ \\
\hline Married & $-0.82(3.88)$ & $-0.21(1.96)$ & -0.004 \\
\hline Working spouse & $13.79^{* * *}(2.65)$ & $2.95^{* *}(1.27)$ & $0.055^{* * *}$ \\
\hline White collar & $-23.78^{* * *}(2.96)$ & $-4.24^{* * *}(1.52)$ & $-0.085^{* * *}$ \\
\hline Job in agriculture & $-26.84^{* * *}(3.80)$ & & $-0.090^{* * *}$ \\
\hline Job in manuf. or constr. & $-7.22^{* *}(3.11)$ & & $-0.040^{* *}$ \\
\hline District unempl. rate & $-4.42^{* * *}(0.72)$ & $-1.23^{* * *}(0.40)$ & $-0.017^{* * *}$ \\
\hline Heckman's $\lambda$ & & $7.33^{* * *}(2.13)$ & \\
\hline Number of observations & 5474 & 798 & 5474 \\
\hline Log likelihood & -5634 & -5127 & \\
\hline
\end{tabular}

Notes: coefficients if not otherwise specified; standard errors in parentheses; * significant at 10 percent, ** at 5 percent, *** at 1 percent; + standard errors corrected for heteroskedasticity; ++ marginal effects of changes in dependent variables (discrete changes in dummies).

Table 8.6: Tobit and Heckman (1979) estimates: jobs with elapsed duration longer than 1 year excluded from the sample.

\begin{tabular}{|l|l|l|l|}
\hline & Total loss & Loss in participation & Loss in hours worked \\
\hline 1996 (mil. CZK) & 20.6 & $13.5(65.6 \%)$ & $7.1(34.4 \%)$ \\
\hline 1996 GDP share (\%) & 0.001 & 0.0009 & 0.0005 \\
\hline 2000 (mil. CZK) & 42.7 & 28.0 & 14.7 \\
\hline 2000 GDP share (\%) & 0.002 & 0.001 & 0.0008 \\
\hline
\end{tabular}

Table 8.7: The pecuniary value of the retired males' labor supply reduction in 1996 and 2000. 


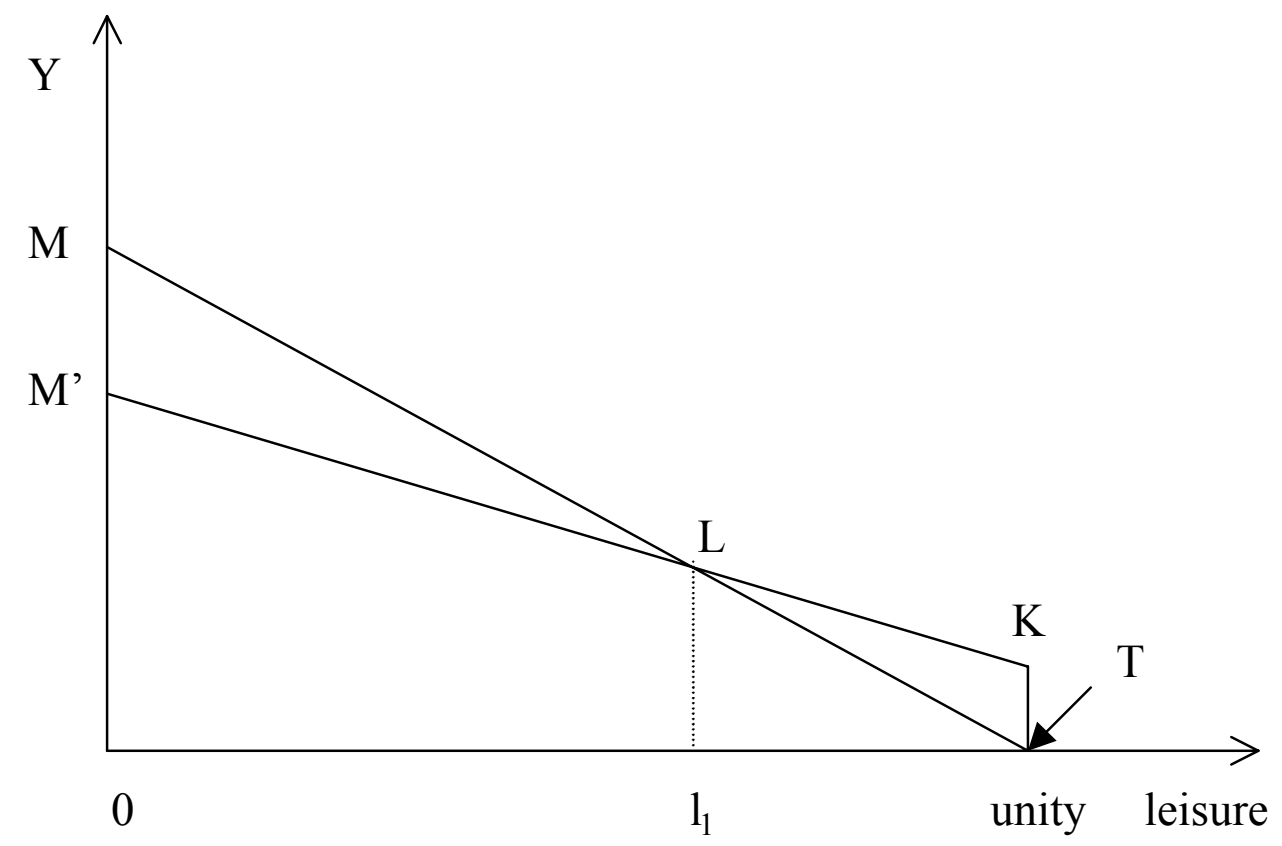

Figure 8.1: Budget constraints in 1995. 


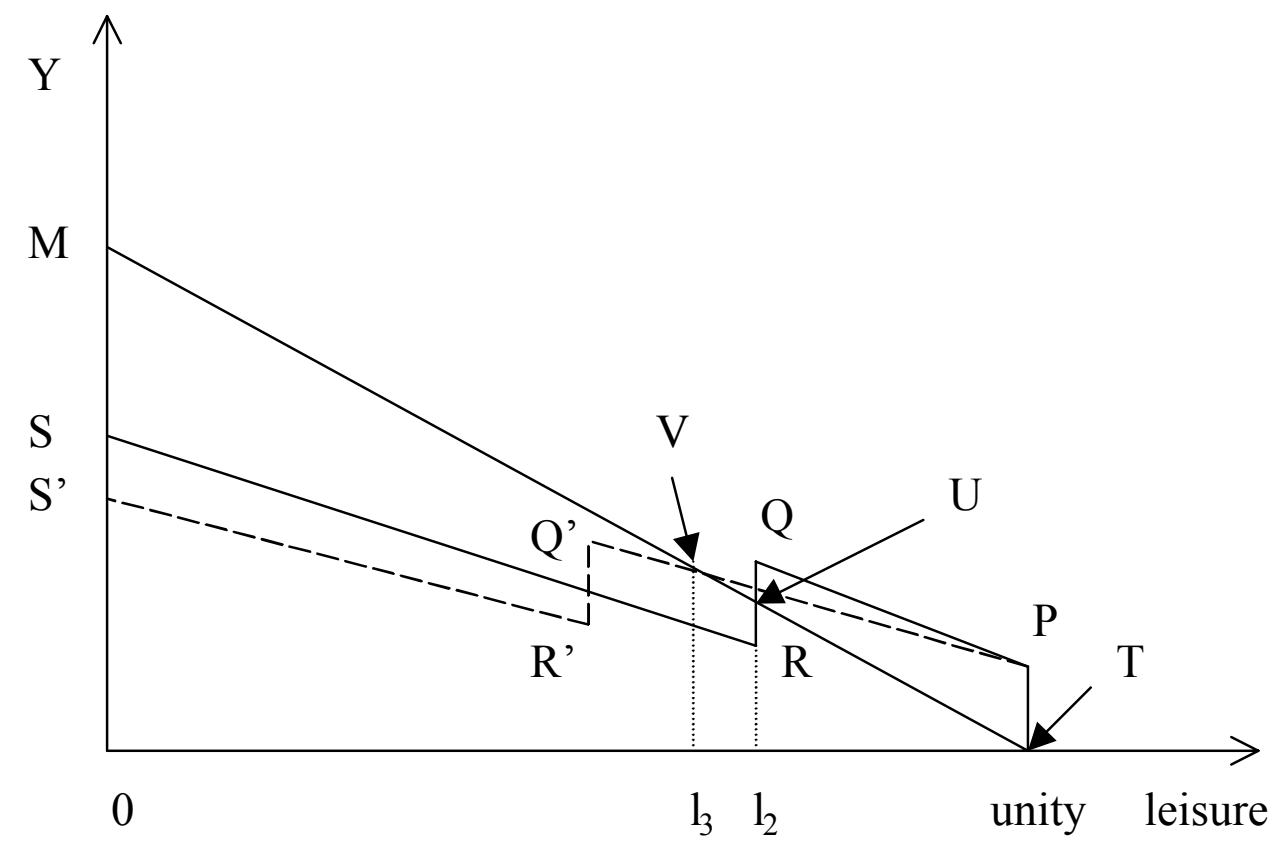

Figure 8.2: Budget constraints in 1996. 


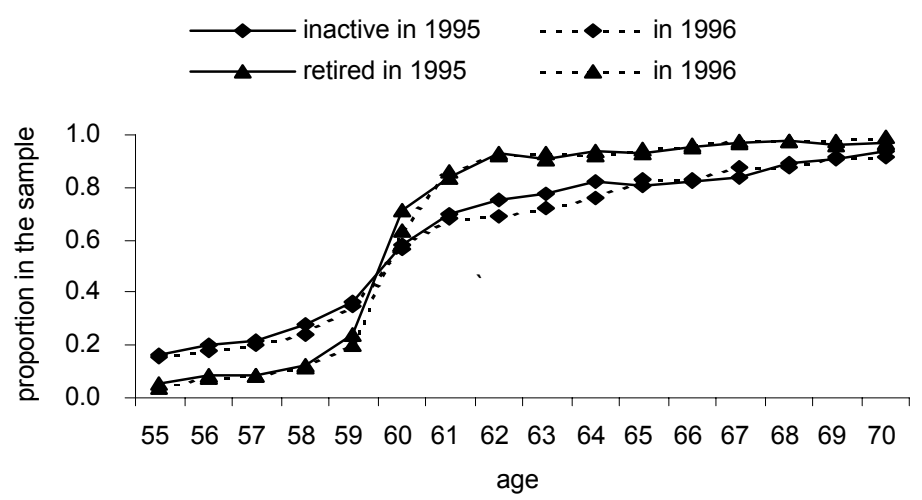

Figure 8.3: Age profile of the labor force status and retirement in 1995 and 1996.

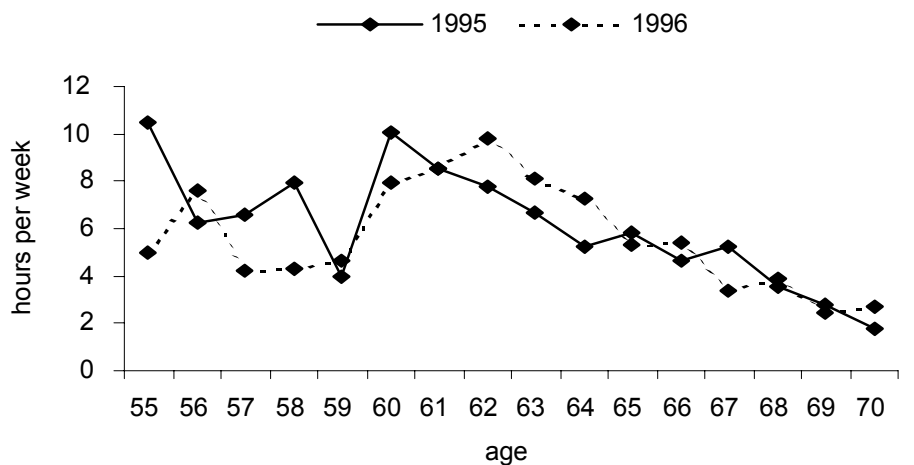

Figure 8.4: Pensioners' hours of work per week in 1995 and 1996. 


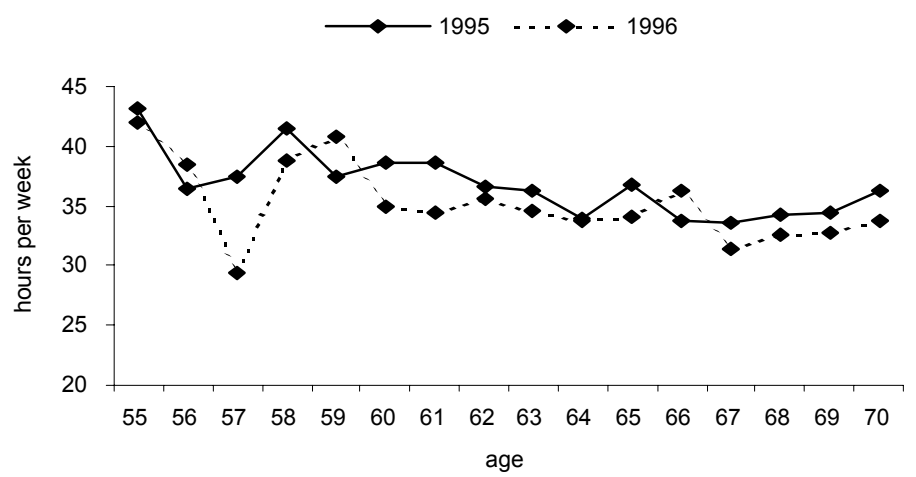

Figure 8.5: Working pensioners' hours of work per week in 1995 and 1996. 